\title{
Metabolism and carbon exchange in microplankton of the Grand Banks (Newfoundland)
}

\author{
Ralph E. H. Smith, W. Glen Harrison, Brian Irwin \& Trevor Platt \\ Department of Fisheries and Oceans, Marine Ecology Lab., Bedford Institute of Oceanography, Dartmouth, Nova Scotia \\ B2Y 4A2, Canada
}

\begin{abstract}
We measured simultaneously the size-distribution of oxygen consumption, inorganic and organic dissolved carbon assimilation, and the standing stocks of phytoplankton and bacteria, to develop simple carbon budgets and ${ }^{14} \mathrm{C}$ exchange models for the microplankton communities of a large continental shelf system. In spring samples (dominated by large-celled diatoms) community respiration consumed 33 to $100 \%$ or more of the gross primary production (GPP) measured by the $\mathrm{O}_{2}$-light-anddark-bottle technique and was apparently due entirely to microheterotrophs. In fall samples (dominated by flagellates) community respiration consumed $100 \%$ or more of the measured GPP, and appeared on average to be due equally to autotrophs and heterotrophs. Primary production, estimated by ${ }^{14} \mathrm{C}-\mathrm{CO}_{2}$ assimilation into particulate matter, often greatly underestimated GPP and community metabolism measured by the $\mathrm{O}_{2}$ technique, with apparent photosynthetic quotients (PQ) of about 5.0 in the spring samples. Modelling of the tracer dynamics suggested large rates of DOC release (>particulate production) from a small and rapidly cycling pool within the autotrophs as the cause of the large apparent PQ's. The large share of primary production consumed by small microheterotrophs $(<5$ or $1 \mu \mathrm{m})$ and frequent lack of positive net community production suggested a law efficiency for the transfer of microheterotrophic production to larger organisms.
\end{abstract}

\section{INTRODUCTION}

There is now considerable evidence that microheterotrophs are often major consumers of primary production in marine microplankton communities. Simple trophic models indicate that $40 \%$ or more of primary production can enter the dissolved organic carbon pool and the microheterotrophic food web of bacteria and their grazers (Williams 1981a, Joint \& Morris 1982, Peterson 1984). Diverse techniques of measurement indicate that bacterial net production (i.e. production after respiration losses but before grazing losses) is from 5 to $25 \%$ of primary production in coastal and shelf waters (Van Es \& Meyer-Reil 1982, Ducklow 1983, Azam et al. 1983, Williams 1984a). Such measurements can be viewed as minimal estimates of total microheterotroph consumption of primary production.

It is still difficult to measure directly the total consumption of primary production by bacteria and other microheterotrophs (Joint \& Morris 1982, Williams 1984a), particularly due to the lack of an established technique for measuring the gross assimilation (net production plus respiration) of carbon by natural bacterial populations. Bacterial net production measurements can be converted to gross assimilation but only with a large uncertainty due to a great range (from 10 to $80 \%$ ) in estimates of bacterial growth efficiency (Joint \& Morris 1982, Newell 1983, Williams 1984a, Bauerfeind 1985). The most appropriate value(s) for growth efficiency is still an open question that can be resolved only through the measurement of both metabolism and production of natural bacteria.

There is nonetheless a variety of evidence that microheterotrophs $(\mathrm{MH})$ may frequently consume most or all of primary production in some marine microplankton communities (Packard \& Williams 1981, Williams et al. 1983, Holligan et al. 1984a, Laanbroek et al. 1985). It is important to know how general such a situation might be because a chronically large $(>50 \%)$ consumption of primary production would raise fundamental challenges to our accepted 
trophodynamic concepts (Pomeroy 1974, Williams 1981a) and could alter our interpretation of primary production measurements (Peterson 1980). In particular, the potential of $\mathrm{MH}$ activity to bias primary production estimates made by ${ }^{14} \mathrm{C}_{1}$ and other techniques, has been a long-standing concern (Peterson 1980, Jackson 1983, Smith et al. 1984). Simultaneous measurements of primary production and its consumption by $\mathrm{MH}$ are, however, still uncommon.

One valuable approach to estimating the consumption of primary production by $\mathrm{MH}$ is through the measurement of $\mathrm{O}_{2}$ production and consumption (Williams 1981a, 1984b). This approach has been pursued and improved with increased analytical precision and with the use of size-fractionation (Bryan et al. 1976, Williams 1981b, Williams \& Jenkinson 1982). The resulting evidence for strong concentration of respiration in small plankton size classes is among the most persuasive evidence that $\mathrm{MH}$ often dominate community respiration and therefore consume a large share of primary production. The separation of the $\mathrm{MH}$ share of total respiration can be difficult, but is often possible if specific indices of auto- and heterotrophic activity are also measured (e.g. Bell \& Kuparinen 1984).

In the present study we used size-fractionated measurements of $\mathrm{O}_{2}$ exchange and of auto- and heterotrophic activity to determine the balance between primary production and community respiration, and the contribution of $\mathrm{MH}$ to community respiration, in the microplankton of a large shelf system, the Grand Banks of Newfoundland. Simultaneously we measured bacterial production rates in pre-screened seawater to assess bacterial growth efficiency. We also attempted to reconcile rates of primary production measured using ${ }^{14} \mathrm{C}$ with the $\mathrm{O}_{2}$ results by means of a simple carbon exchange model. In the samples available $\mathrm{MH}$ metabolism often consumed most of the apparent primary production, while primary production itself appeared to be underestimated by rates of ${ }^{14} \mathrm{C}$ assimilation into particulate matter.

\section{MATERIALS AND METHODS}

We visited the Grand Banks at 3 different times during 1984: April (C.S.S. Hudson, Cruise \#84-010); July (C.G.S. Wilfred Templeman, Cruise \#84-015); and October (C.S.S. Dawson, Cruise \#84-028). The sites sampled (Fig. 1) were on or near the Southeast Shoal. In April and October, water was sampled using a submersible pumping system (Herman et al. 1984) or by Niskin bottles, and in July by Niskin bottles only. Salinity, pressure and temperature profiles were measured on all cruises. In April and October, in vivo fluorescence of chlorophyll a (Chl a) was also profiled using a submersible fluorometer (Aquatracka). On all 3 cruises, Chl a was also measured on samples (100 to $200 \mathrm{ml}$ ) from 6 to 8 discrete depths, using fluorometry of acetone extracts and calibration against pure $\mathrm{Chl} a$.

Experimental incubations were done in deck boxes cooled by running surface sea water. Periodic measurements showed that the boxes were less than $2^{\circ} \mathrm{C}$ above in situ surface temperature. White linen covers and nickel screening were used to attenuate light to

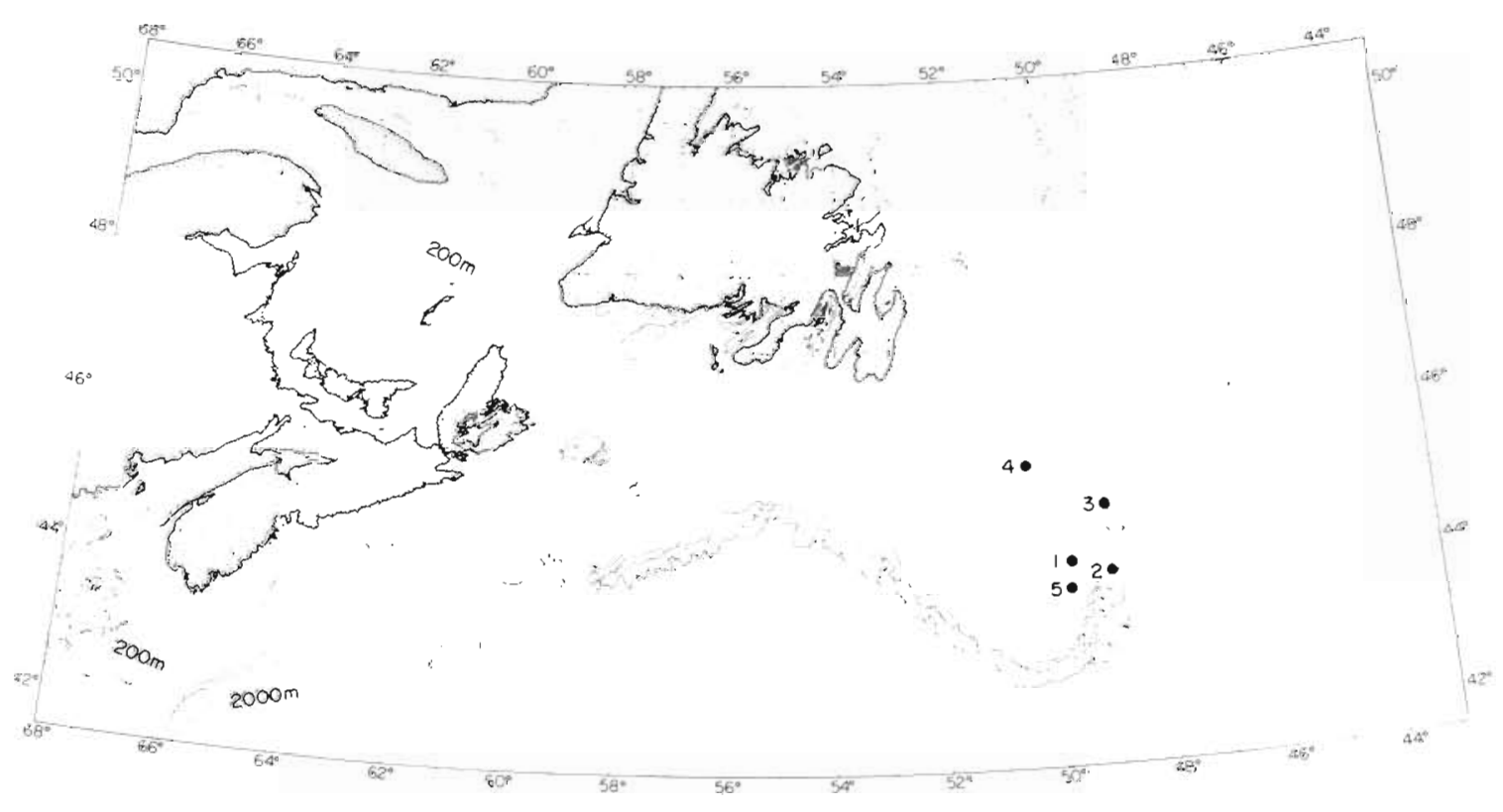

Fig. 1. Sampling locations on the Grand Banks; numbers denote stations listed in Table 1 
$70 \%$ and $10 \%$, respectively, of incident. Black cloth bags covered the boxes by night to exclude stray deck light.

To size-fractionate the plankton prior to incubation we used, in April and July, reverse filtration through nylon mesh (Nitex) of 200, 10, or $5 \mu \mathrm{m}$ nominal pore size. In October, we used gentle gravity filtration through nylon mesh (5 $\mu \mathrm{m}$ pore size) or polycarbonate membrane filters (Nuclepore; $1 \mu \mathrm{m}$ pore size). Filtration of the different size classes was always parallel rather than serial.

Oxygen exchange rates were measured in acidcleaned, $125 \mathrm{ml}$ borosilicate glass bottles. In April, ${ }^{14} \mathrm{C}$ $\mathrm{CO}_{2}$ assimilation was measured in parallel incubation in the same type of bottles, while additional bottles were incubated for periodic assessment of bacterial abundance, chlorophyll a concentration, and assimilation of tritiated glucose and amino acids. In July and October, all incubations except those for $\mathrm{O}_{2}$ were done, for convenience, in larger polycarbonate bottles $(0.5$ to 2.01 ). Occasional comparisons did not reveal significant differences in either organic or inorganic carbon assimilation rates as a function of bottle type.

Experimental incubations usually started at dawn, but occasionally at noon. When started at dawn, bottles were removed at dusk and at the following dawn (and for dark bottles, sometimes more frequently) in groups of 4 replicates and analyzed for $\mathrm{O}_{2}$ concentration. When started at noon, bottles were removed at dusk and the following noon. We used a high-precision, automated, Winkler method (Bryan et al. 1970 , Williams \& Jenkinson 1982) for $\mathrm{O}_{2}$ analysis.

Assimilation of ${ }^{14} \mathrm{C}-\mathrm{CO}_{2}$ was measured at similar intervals except that we always included both dusk and following dawn measurements to assess overnight loss or assimilation. In dawn experiments, we also continued the ${ }^{14} \mathrm{C}$ incubations to the second noon to assess the assimilation rates after lengthy confinement and exposure to tracer. Parallel dark bottle controls generally indicated negligible assimilation compared to illuminated samples, with the exception of the smaller size fractions on April 14 and 16. We did not subtract the dark bottle values but, as will be shown in the next section, this decision had little bearing on the interpretation of the data.

We measured particulate organic ${ }^{14} \mathrm{C}$ activity by liquid scintillation spectrometry of samples which had been collected (cellulose acetate filters, $0.45 \mu \mathrm{m}$ porc size) under gentle pressure $(<50 \mathrm{~mm} \mathrm{Hg}$ ), rinsed with filtered sea water, and acidified to drive off residual inorganic label. To measure dissolved organic ${ }^{14} \mathrm{C}$, the filtrate and rinse was acidified and the residual activity determined by liquid scintillation spectrometry (Smith \& Platt 1984). Total activities were measured on aliquots mixed with a $\mathrm{CO}_{2}$-trapping agent $(\mathrm{NaOH})$. All counts were corrected for quenching by the Compton edge displacement $(\mathrm{H \# )}$ method. No isotope discrimination factor was used.

We measured the rate of assimilation of tritiated glucose (New England Nuclear \#NET-100A) and/or of tritiated amino acid mixture (NEN \#NET-250) in 4 to 8 separate incubations initiated at different times during most of the diurnal experiments. In each incubation, we sampled at time-zero, 0.5 and $1.0 \mathrm{~h}$ (approximately). Samples were filtered onto $0.45 \mu \mathrm{m}$ pore cellulose acetate filters ( $<50 \mathrm{~mm} \mathrm{Hg}$ pressure), rinsed with filtered sea water, and counted by liquid scintillation spectrometry. Occasional comparisons against $0.2 \mu \mathrm{m}$ pore polycarbonate filters revealed no significant difference in activity retained. In April and July, tracer solution was added to a final activity of 20 to $80 \mu \mathrm{Ci} \mathrm{l}^{-1}$, equivalent to 0.5 to $2.0 \mathrm{nM}$ added substrate for both glucose and amino acids. In October, smaller additions were used ( 2 to $10 \mu \mathrm{Ci} \mathrm{l}^{-1}$, or 0.05 to $0.25 \mathrm{nM}$ ). The turnover rate of the added organic tracers was approximated as the rate of assimilation into particulate matter divided by the total concentration of added tracer.

The concentration of bacterial cells was determined by epifluorescent microscopy of DAPI stained samples (Coleman 1980, Porter \& Feig 1980). In most experiments, samples for enumeration were taken 4 to 8 times during the diurnal incubation. To estimate bacterial cell volume, photographs were taken under epifluorescence, the slides projected at $20000 \times$ final magnification, cell dimensions measured and volumes then calculated by geometric approximation. Cell volumes were converted to carbon content assuming that bacterial cell carbon is $20 \%$ of wet weight (Bratback \& Dundas 1984).

Samples for phytoplankton and microzooplankton enumeration (150 to $300 \mathrm{ml})$ were preserved with either Lugol's iodine or formalin, and were examined under phase contrast at 40 to $400 \times$ final magnification. Autotrophic carbon biomass was estimated as $50 x$ Chl a (cf. Eppley et al. 1977).

We follow Strickland (1960) and Smith et al. (1984) in our calculation and definition of production rates. Gross primary production (GPP) is the photosynthetic rate before any losses while net community production (CP) is the photosynthetic rate after all losses, including both autotrophic and heterotrophic respiration, in the microplankton community. $\mathrm{CP}$ is accordingly the production available for export from the microplankton. In operational terms, it is traditional to assume that $\mathrm{O}_{2}$ consumption in dark bottles measures community respiration while $\mathrm{O}_{2}$ change in light bottles measures $C P$; GPP is thus defined as the sum of the (absolute) changes of concentration in light and dark bottle (Strickland 1960). By contrast, the question of which 
production level (GPP, CP, or something else) is measured by ${ }^{14} \mathrm{C}$ is still a largely open question.

\section{RESULTS}

\section{Plankton abundance and primary production}

Our observations fell into 2 groups on the basis of water column structure and phytoplankton species composition. The first group comprised all the April samples, obtained from cold and deeply-mixed water (Table 1). The phytoplankton was dominated by largecelled diatoms, especially large numbers of Rhizosolenia and Coscinodiscus spp. The second group comprised the July and October samples, which were obtained either from the surface mixed layer or just below in the pycnocline (Table 1). Stratification was strong, and surface temperatures relatively high, in July and October. The phytoplankton was dominated by flagellates, including many Gymnodinium and Gyrodinium spp. In October only, there was also an abundance of large-celled dinoflagellates, including Ceratium, Dinophysis and Peridinium spp.

Chlorophyll a concentrations varied by about 1 order of magnitude within each group (Table 2). The highest chlorophyll a concentrations and gross primary production (GPP) rates were observed in April, but only at the edge of the shelf (Stn 2, Fig. 1); the nearby station on the shelf itself (Stn 1) had chlorophyll a concentrations and GPP no higher than those observed in July and October (Table 2). The relatively productive shelfedge station was in fact the only one at which we measured any excess of GPP over respiratory consumption. Even in October samples with relatively large chlorophyll a concentrations, respiration equalled or exceeded GPP in $24 \mathrm{~h}$ incubations (Table 2).

Table 1. Sampling stations (cf. Fig. 1); depths of stations, sampling, mixed layer $(\mathrm{Zm})$ and Chl a in vivo fluorescence maximum (Zchl; no maximum in Apr) and water temperature at sampling depth

\begin{tabular}{|c|c|c|c|c|c|c|}
\hline \multirow[t]{2}{*}{ Date (1984) } & \multirow[t]{2}{*}{ Station } & \multicolumn{4}{|c|}{ Depths (m) } & \multirow[t]{2}{*}{ Temp. $\left({ }^{\circ} \mathrm{C}\right.$} \\
\hline & & Stn & Sample & $\mathrm{Zm}$ & Zchl & \\
\hline $12 \mathrm{Apr}$ & 1 & 40 & 10 & 40 & - & 2.5 \\
\hline $14 \mathrm{Apr}$ & 2 & 200 & 10 & 200 & - & 2.5 \\
\hline $16 \mathrm{Apr}$ & 2 & 200 & 10 & 200 & - & 2.5 \\
\hline $16 \mathrm{Jul}$ & 3 & 133 & 6 & 15 & 35 & 11.0 \\
\hline $17 \mathrm{Jul}$ & 4 & 80 & 6 & 15 & 35 & 12.7 \\
\hline 4 Oct & 5 & 45 & 20 & 20 & 25 & 12.8 \\
\hline $5 \mathrm{Oct}$ & 5 & 45 & 10 & 20 & 25 & 13.5 \\
\hline 7 Oct & 5 & 45 & 27 & 20 & 25 & 9.5 \\
\hline 9 Oct & 5 & 45 & 34 & 20 & 25 & 9.5 \\
\hline
\end{tabular}

Table 2. Oxygen exchange (community respiration, $\mathrm{R}$, and gross primary production, GPP, both estimated from linear regression of changes over $24 \mathrm{~h}$ ), chlorophyll a concentration $(\mathrm{Chl}$ a) and bacterial cell concentration, all $\pm 95 \%$ confidence interval, and dissolved organic substrate (DOC) turnover rate. Turnover rates are for glucose $\left({ }^{\circ}\right)$ or amino acids $\left({ }^{\prime}\right)$ ) or the average of both $(\cdots)$; the ranges shown are the greater of either $95 \% \mathrm{Cl}$ of replicate measurements or the range of values observed during the diurnal incubation (see text)

\begin{tabular}{|c|c|c|c|c|c|}
\hline $\begin{array}{c}\text { Date } \\
(1984)\end{array}$ & $(\mu \mathrm{gC}$ & $\begin{array}{l}\text { GPP } \\
\mathrm{h}^{-1} \mathrm{~J}\end{array}$ & $\begin{array}{l}\text { Chl a } \\
\left(\mu \mathrm{gl} \mathrm{l}^{-1}\right)\end{array}$ & $\begin{array}{c}\text { Bacteria } \\
\left(10^{6} \text { cells } \mathrm{ml}^{-1}\right)\end{array}$ & $\begin{array}{c}\text { DOC turnover } \\
\qquad\left(\mathrm{h}^{-1}\right)\end{array}$ \\
\hline 12 Apr & $3.51 \pm 0.90$ & $2.93 \pm 2.18$ & $0.41 \pm 0.049$ & $4.44 \pm 0.24$ & $0.0065 \pm 0.0010^{\circ}$ \\
\hline $14 \mathrm{Apr}$ & $7.26 \pm 1.98$ & $11.64 \pm 3.23$ & $3.93 \pm 0.37$ & $1.67 \pm 0.17$ & $0.0063 \pm 0.0011 \cdots$ \\
\hline $16 \mathrm{Apr}$ & $4.16 \pm 1.28$ & $12.61 \pm 4.38$ & $3.96 \pm 0.24$ & $1.79 \pm 0.20$ & $0.0025 \pm 0.0003^{\circ}$ \\
\hline $16 \mathrm{Jul}$ & $6.09 \pm 1.37$ & na & $0.27 \pm 0.017$ & $3.094 \pm 0.14$ & $0.00083(0.00063-0.0023) \cdots$ \\
\hline $17 \mathrm{Jul}$ & $3.96 \pm 1.06$ & $3.97 \pm 1.56$ & $0.14 \pm 0.016$ & $1.765 \pm 0.09$ & $0.0033(0.0027-0.0400)^{\cdots} \cdot$ \\
\hline 4 Oct & $12.90 \pm 1.39$ & na & $1.573 \pm 0.047$ & $1.896 \pm 0.07$ & $0.0028 \pm 0.0004^{\cdots}$ \\
\hline 5 Oct & $4.27 \pm 0.93$ & $3.11 \pm 1.11$ & $0.577 \pm 0.047$ & $1.878 \pm 0.31$ & $0.0061(0.0046-0.0448)^{\cdots}$ \\
\hline 7 Oct & $8.96 \pm 1.43$ & $5.17 \pm 1.91$ & $1.852 \pm 0.069$ & 1.878 & $0.0192(0.0169-0.0372)^{\cdots}$ \\
\hline 9 Oct & $10.70 \pm 1.56$ & na & $0.412 \pm 0.083$ & $0.597 \pm 0.02$ & na \\
\hline
\end{tabular}




\section{Bacterial abundance and production}

The concentration of bacterial cells was conservative among sampling dates, most values being close to 2.0 million cells $\mathrm{ml}^{-1}$ (Table 2). We did not generally find clear or consistent changes in bacterial abundance during the diurnal incubations. On one sampling date only (July 17) we observed roughly exponential population dynamics (increasing) in both the $<200$ and $<5 \mu \mathrm{m}$ fractions. Otherwise, cell concentrations commonly decreased either initially or for the duration of the incubation. Table 3 tabulates the cell concentration changes observed over 24 h of incubation.

Table 3. Change in bacterial population size observed over 24 $\mathrm{h}$ of incubation in different prescreened size fractions (as \% of cells $\mathrm{ml}^{-1}$ at time-zero)

\begin{tabular}{|cccccc|}
\hline $\begin{array}{c}\text { Date } \\
(1984)\end{array}$ & \multicolumn{5}{c}{ Nominal upper size limit of fraction $(\mu \mathrm{m})$} \\
& 200 & 20 & 10 & 5 & 1 \\
\hline $12 \mathrm{Apr}$ & -3.0 & -17.0 & 0.0 & -9.0 & - \\
$14 \mathrm{Apr}$ & -15.0 & -23.0 & -23.0 & -15.0 & - \\
$16 \mathrm{Apr}$ & 16.0 & -14.0 & -1.0 & -2.0 & - \\
$16 \mathrm{Jul}$ & 0.0 & - & - & 9.0 & - \\
$17 \mathrm{Jul}$ & 65.0 & - & - & 36.0 & - \\
5 Oct & 20.0 & - & - & -13.0 & 25.0 \\
7 Oct & 0.0 & - & - & 6.0 & -18.0 \\
9 Oct & - & - & - & - & 3.0 \\
& & & & & \\
$-:$ no data & & & & & \\
\hline
\end{tabular}

There was no clear or consistent evidence for a significant grazing pressure on the bacteria, as 5 and/or $1 \mu \mathrm{m}$ screens failed to permit consistently greater growth. In fact, considering the statistical error associated with the cell counts $(95 \%$ confidence interval about $15 \%$ of the mean), there was little evidence for significant change of cell concentration in most experiments.

We did not find significant changes in bacterial biovolume during incubation. In October, mean cell volumes ranged from 0.069 to $0.085 \mu \mathrm{m}^{3}$ among all experiments, and in July from 0.062 to $0.094 \mu \mathrm{m}^{3}$. We did not measure bacterial biovolume in April, but there was no subjectively apparent increase of biovolume, or change in morphology, during the incubations and no obvious difference from the October and July populations. It appeared that bacterial biomass production was, like cell production, generally not significantly different from zero even in our smallest size fractions.

The turnover rates of glucose and amino acids agreed, within a factor of 2 , whenever both were measured together (April 14, July 16, 17, and October 5). Turnover rates in freshly collected water were, on average, similar between April and the later sampling dates (Table 2). However, turnover rates sometimes increased during the diurnal incubations in July and October, but not in April; the resulting diurnal average turnover rates were accordingly often higher in July and October than in April (Table 2). We failed (except on July 17) to detect corresponding increases of bacterial biomass, as described above, despite our particular efforts to identify them when the organic tracer turnover rates increased with time.
Fig. 2. Cumulative size distributions of $\mathrm{O}_{2}$ consumption rates $(x$, with bars indicating the $95 \%$ CI), bacterial biomass $(\Delta)$, Chl. a concentrations (-) and ${ }^{14} \mathrm{C}-\mathrm{CO}_{2}$ assimilation rates $(\mathrm{O})$ in Apr samples. Sizes are defined by size of mesh through which water was filtered (= nominal upper size limit) before measurements, and are plotted on a $\log (2)$ scale. The largest size class $(<200 \mu \mathrm{m})$ by definition contains $100 \%$ of each measured property, and smaller classes $k 5$, $<10,<20 \mu \mathrm{m})$ some lesser fraction. Statistical imprecision can give apparently $>100 \%$ in small size classes when small organisms dominate (e.g. $\mathrm{O}_{2}$ consumption, Apr 12)
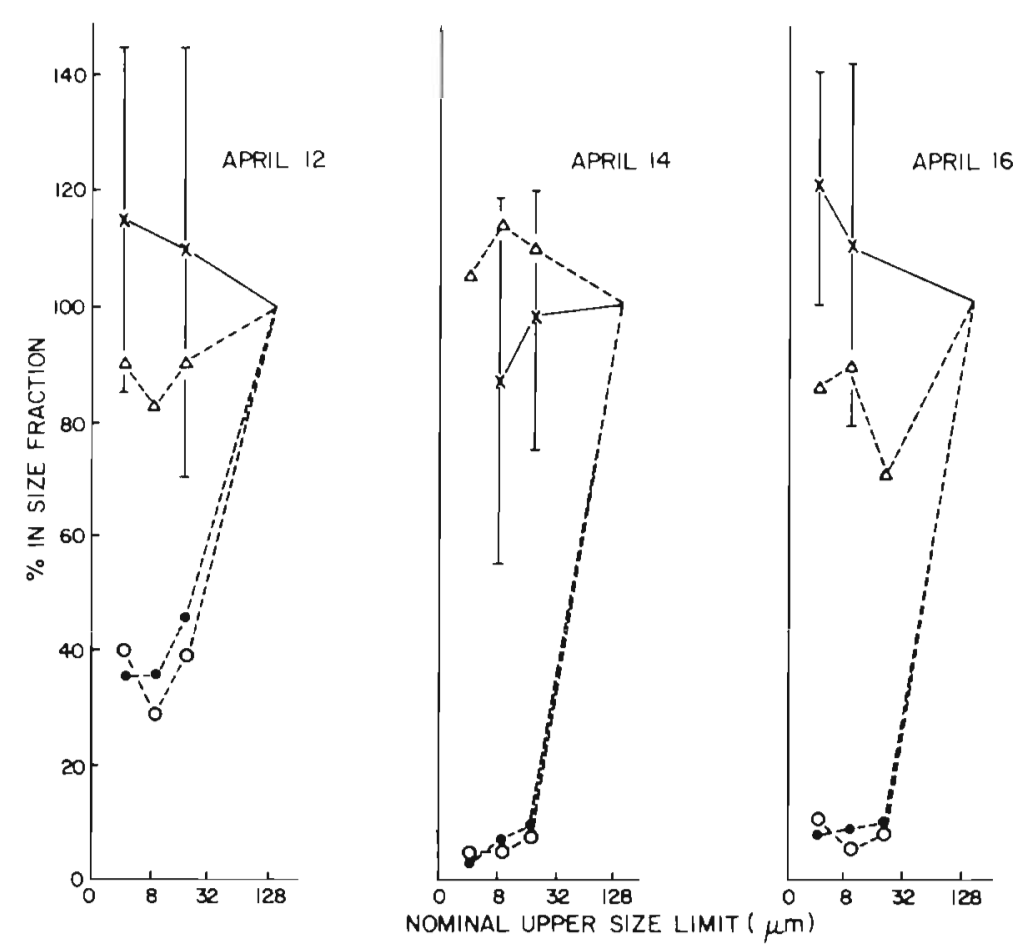


\section{Autotroph and heterotroph metabolism}

The April data were distinct from those of July and October in the size distribution of plankton organisms and their metabolic activity. The large-celled diatoms (retained by $20 \mu \mathrm{m}$ mesh) of the spring samples accounted for about $60 \%$ (April 12) or $90 \%$ (April 14, 16) of the chlorophyll $\mathrm{a}$ and ${ }^{14} \mathrm{C}-\mathrm{CO}_{2}$ assimilation (Fig. 2). By contrast, respiration rates, bacterial abundance, and turnover rate of DOC (dissolved organic carbon, i.e. glucose and/or amino acids) were not significantly diminished even by $5 \mu \mathrm{m}$ screening. Apparent instances of more than $100 \%$ of respiration or bacterial biomass in the smaller fractions (Fig. 2) probably reflect statistical error and dominance of small organisms. These observations strongly suggested that community respiration was mainly or entirely associated not with the primary producers but with heterotrophs in the $<5 \mu \mathrm{m}$ fraction.

In July and October, both chlorophyll $a$ and ${ }^{14} \mathrm{C}-\mathrm{CO}_{2}$ assimilation were largely associated with the smaller size fractions. In July, our smallest mesh was $5 \mu \mathrm{m}$, which failed to remove any substantial proportion of $\mathrm{Chl} \mathrm{a},{ }^{14} \mathrm{C}-\mathrm{CO}_{2}$ assimilation, bacterial cells, DOC assimilation, or respiration. Thus it was impossible to discriminate the relative contributions of autotrophs and heterotrophs to community metabolism in July. In October, the size distributions of populations and metabolic activities varied among sampling dates
(Fig. 3). Most of the autotrophic activity (Chl a and ${ }^{14} \mathrm{C}$ $\mathrm{CO}_{2}$ assimilation) was in the $<5 \mu \mathrm{m}$ fraction, and up to roughly $50 \%$ was in the $<1 \mu \mathrm{m}$. The proportion of respiratory activity passing the $1 \mu \mathrm{m}$ screen was consistently greater than the proportion of autotrophic activity (Fig. 3). Bacterial abundance and DOC turnover rate were not significantly reduced by 1 or $5 \mu \mathrm{m}$ screening. Together, the observations were consistent with the view that both autotrophs and heterotrophs contributed to community respiration, but in varying proportions among the different experiments in October.

We estimated the ratio of autotrophic respiration $\left(R_{A}\right)$ to community respiration (R) in October by the formula:

$$
\begin{gathered}
\mathrm{R}_{\mathrm{A}} / \mathrm{R}=(\% \text { respiration }>1 \mu \mathrm{m}) /\left(\%{ }^{14} \mathrm{C}\right. \text { assimilation } \\
>1 \mu \mathrm{m})
\end{gathered}
$$

We chose the $1 \mu \mathrm{m}$ screen because it yielded the greatest difference between autotrophic and heterotrophic activities, and thus a more sensitive measure than the $5 \mu \mathrm{m}$ screen. In using Equation (1) we assumed, like Bell \& Kuparinen (1984), that autotrophic respiration was directly proportional to autotroph abundance and photosynthetic activity over all size classes. The estimates of $R_{A} / R$ ranged from 0.0 on October 5 to 0.70 on October 4 . The average value for all the October experiments was 0.50 .
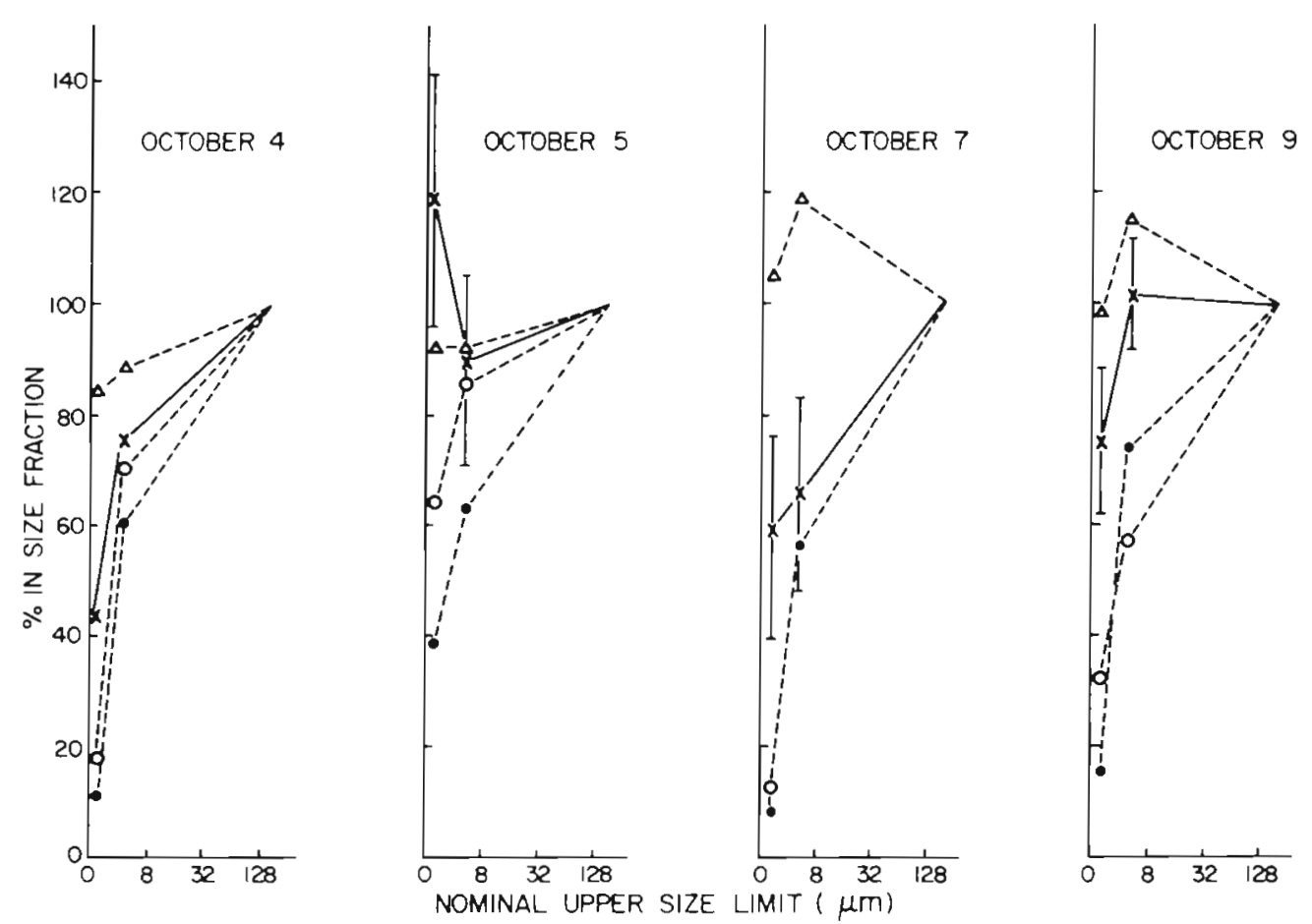

Fig. 3. Cumulative size distributions for Oct samples. As Fig. 2 except size classes are $<200,<5$ and $<1 \mu m$ 


\section{Carbon budgets}

The foregoing data allowed us to calculate carbon budgets, based on a simple exchange model, for April and October. The model (Fig. 4) was a simplified version of others commonly used to describe material flow in the microplankton (e.g. Peterson 1984, Fasham 1985) and was intended primarily to account for ${ }^{14} \mathrm{C}$ movement through the autotrophs (see below). The model consequently ignored grazing by microheterotrophs, the use by bacteria of substrates other than phytoplankton exudate and the possibility of natural (non-grazing) mortality of bacteria (cf. Servais et al. 1985). The DOC pool of the model was intended to represent only the pool of labile products released from phytoplankton. These simplifications were also largely justifiable by our failure to measure a major grazing pressure on small particles (bacteria) and by the fact that natural mortality of bacteria is essentially a closed loop that has little bearing on the modelling of tracer flow or the net flow of carbon to higher trophic levels.

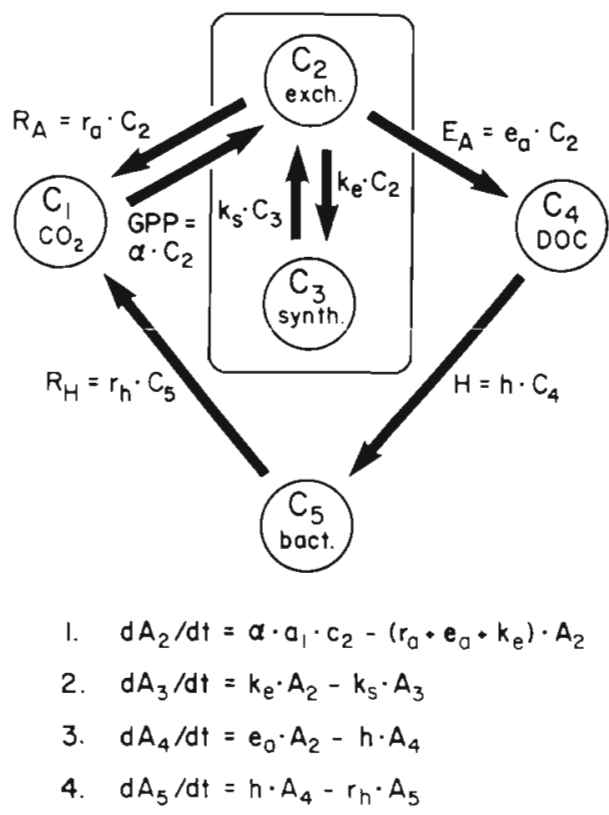

Fig. 4. Carbon exchange model used in constructing carbon budgets (Table 4), together with the corresponding equations for ${ }^{14} \mathrm{C}$ tracer dynamics ( $\mathrm{dA} / \mathrm{dt}$ ) used to model tracer flow. Pools $\mathrm{C}_{2}$ and $\mathrm{C}_{3}$ together comprise the autotroph carbon pool. Carbon fluxes are defined as the product of carbon pool size $\left(\mathrm{C}_{\mathrm{i}}\right)$ and rate constant, as shown in the schematic, while tracer fluxes are the product of pool activity $\left(\mathrm{A}_{j}\right)$ and rate constant. The rate constants (all normalized to pool of origin) are autotroph respiration $\left(\mathrm{r}_{\mathrm{a}}\right)$, autotroph DOC release $\left(\mathrm{e}_{\mathrm{d}}\right)$, DOC assimilation by bacteria $(\mathrm{h})$, exchanging to synthetic pool transfer $\left(k_{e}\right)$, synthetic to exchanging pool transfer $\left(k_{s}\right)$ and heterotrophic respiration $\left(\mathrm{r}_{h}\right)$. Gross photosynthetic rate, $\alpha$, is normalized to the autotrophic exchanging pool and is zero by night. In Eqn $1 ., a_{1}$ denotes the specific activity of dissolved inorganic carbon (assumed constant)
For these reasons, we found it useful to present, at least for illustrative purposes, the carbon budgets that result if the model's simplifications are entertained.

In a departure from most such material flow models, we postulated the existence of 2 , functionally-distinct, pools within the autotrophs (Fig. 4). While critical to the tracer flow modelling, this distinction can be ignored for the purpose of developing carbon budgets.

To construct the budgets (Table 4 ) we assumed a respiratory quotient of 0.8 and a photosynthetic quotient (PQ) of 1.25 (Harris 1978, Williams et al. 1979, Burris 1980, Williams 1981b) and an approximate steady-state in bacterial biomass (consistent with our measurements). These assumptions defined the fluxes of GPP, algal and bacterial respiration, and bacterial gross assimilation in carbon units. If we additionally assume a steady state in the DOC pool size, then phytoplankton extracellular release rate must equal

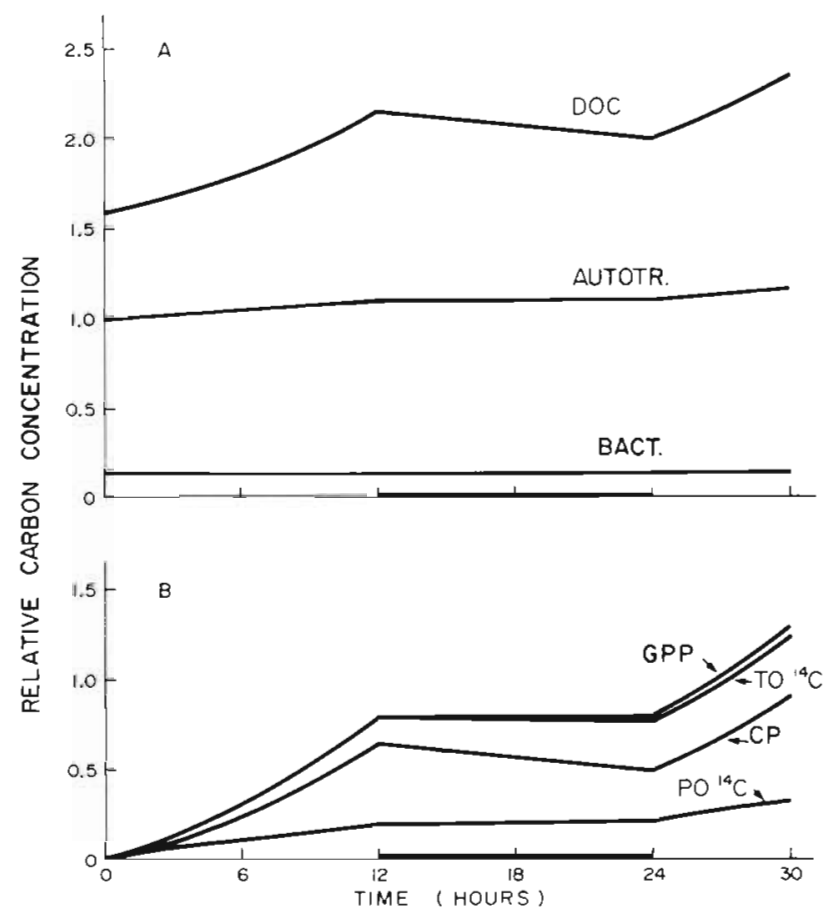

Fig. 5. Results of simulation modelling for Apr 14. The model (Fig. 4) was run with the parameters and initial pool sizes shown in Tables 4 and 5. As in all simulations, photosynthesis $(\alpha)$ and DOC release $\left(e_{a}\right)$ operated only during the $12 \mathrm{~h} \mathrm{light}$ period. All pool sizes (A) and integrated fluxes (B) are expressed in carbon units, scaled relative to an initial autotroph biomass of 1.0 units. (A) Relative dynamics of the dissolved organic carbon (DOC), autotroph (autotr.), and bacterial (bact.) carbon pools. (B) Dynamics of gross photosynthetic carbon fixation (GPP, the integral of $\alpha \mathrm{C}_{2}$ ); net community production, $C P$ (the integrated, community gain in total fixed carbon); the carbon fixed in particulate form, as estimated from ${ }^{14} \mathrm{C}\left(\mathrm{PO}^{14} \mathrm{C}\right)$; and the total carbon fixed as estimated by ${ }^{14} \mathrm{C}\left(\mathrm{TO}^{14} \mathrm{C}\right)$. In all the Apr experiments, autotroph respiration $\left(R_{A}\right)$ was zero, so net primary production equalled GPP throughout 
Table 4. Carbon budgets, calculated according to exchange model (Fig. 4), for diurnal (24 h) experiments. Pools ( $\mu$ g C $1^{-1}$ ), fluxes (upper case letters; $\mu \mathrm{g} \mathrm{C} 1^{-1} \mathrm{~d}^{-1}$ ) and corresponding rate constants (lower case letters; $\mathrm{d}^{-1}$ ) are defined in Fig. 4, with the exception that autotroph respiration and excretion $\left(\mathrm{r}_{\mathrm{a}}, \mathrm{e}_{\mathrm{a}}\right)$ are normalized here to the entire autotroph carbon pool rather than to the exchanging pool. Gross primary production (GPP, $\mu \mathrm{g} \mathrm{C} \mathrm{l}^{-1} \mathrm{~d}^{-1}$ ) was measured both by $\mathrm{O}_{2}$ and by ${ }^{14} \mathrm{C}$. See text for further explanations

\begin{tabular}{|c|c|c|c|c|c|c|c|c|c|}
\hline \multirow{3}{*}{$\begin{array}{c}\text { Date } \\
(1984)\end{array}$} & \multicolumn{3}{|c|}{ Pool sizes } & \multicolumn{6}{|c|}{ Rates } \\
\hline & \multirow[t]{2}{*}{ Autotrophs } & \multirow{2}{*}{ Bacteria } & \multirow[t]{2}{*}{$\mathrm{DOC}$} & \multirow{2}{*}{$\begin{array}{l}R_{A} \\
\left(r_{a}\right)\end{array}$} & \multirow{2}{*}{$\begin{array}{l}\mathrm{R}_{\mathrm{H}} \\
\left(\mathrm{I}_{\mathrm{H}}\right)\end{array}$} & \multirow{2}{*}{$e_{A}$} & \multirow[t]{2}{*}{ h } & \multicolumn{2}{|c|}{ GPP } \\
\hline & & & & & & & & $\mathrm{O}_{2}$ & ${ }^{14} \mathrm{C}$ \\
\hline $12 \mathrm{Apr}$ & 20.5 & 75.1 & 187.2 & $\approx 0$ & $31.6 \quad(0.42)$ & 1.54 & 0.156 & 21.1 & 5.9 \\
\hline $14 \mathrm{Apr}$ & 196.5 & 28.2 & 400.0 & $\approx 0$ & $65.3 \quad(2.32)$ & 0.33 & 0.151 & 83.8 & 22.5 \\
\hline $16 \mathrm{Apr}$ & 198.0 & 30.3 & 604.8 & $\approx 0$ & $37.4 \quad(1.23)$ & 0.19 & 0.060 & 90.7 & 19.9 \\
\hline $4 \mathrm{Oct}$ & 78.5 & 31.7 & 583.5 & $75.6(0.96)$ & $40.56(1.28)$ & 0.52 & 0.067 & na & 29.4 \\
\hline 5 Oct & 28.8 & 28.4 & 103.0 & $\approx 0$ & $38.4 \quad(1.35)$ & 1.33 & 0.317 & 22.3 & 17.0 \\
\hline 7 Oct & 35.0 & 35.0 & 45.7 & $38.7(0.42)$ & $41.9 \quad(1.20)$ & 0.45 & 0.650 & 37.2 & 13.5 \\
\hline 9 Oct & 20.6 & 16.2 & na & $31.8(1.54)$ & $64.5 \quad(3.98)$ & 3.98 & na & na & 4.2 \\
\hline
\end{tabular}

bacterial gross assimilation rate (Table 4) and the DOC pool size must be;

$$
(\mathrm{DOC})=(\text { DOC release rate }) /(\text { DOC turnover rate })
$$

In all cases, we used an average value for DOC turnover rate during the entire diurnal experiment.

Specific rates of autotroph and heterotroph respiration and of extracellular release from autotrophs were calculated from the pool size and flux estimates (Table 4).

The most prominent feature of the budgets was the consistently major role for bacterial metabolism, the importance of extracellular release from autotrophs, and the generally small contribution of autotroph respiration. The pool of DOC that mediated the autotroph to bacteria transfer was apparently larger and more slowly-cycled than the living carbon pools, especially in April. The flow of carbon to DOC and the bacteria accounted for about half (April 14,16) or all (April 12, October 5,7) of the measured gross primary production, GPP (Table 4 ).
In Table 4, we also present primary production rates calculated from our measurements of short-term ( 4 to $6 \mathrm{~h}){ }^{14} \mathrm{C}$ assimilation into particulate matter. Following recent suggestions (Williams et al. 1979, Williams et al. 1983, Holligan et al. 1984b, Smith et al. 1984) that such rates should agree with GPP to within a factor of 2 , we tentatively identified the ${ }^{14} \mathrm{C}$ estimates as alternative measures of GPP. We observed, however, that the ${ }^{14} \mathrm{C}$ rates were more than 2 -fold smaller than GPP estimated by $\mathrm{O}_{2}$ in all the April experiments and on October 7 . The ${ }^{14} \mathrm{C}$-based rates were also much smaller than necessary to balance community respiration (Table 4).

\section{Tracer exchange modelling}

The object of the tracer exchange modelling was to determine whether the apparently low ${ }^{14} \mathrm{C}$ primary production estimates could be reconciled with the $\mathrm{O}_{2}$ results in terms of the simple model in Fig. 4 while simultaneously satisfying 2 other features of the tracer

Table 5. Inorganic carbon fixation rates $\left(\mu \mathrm{g} \mathrm{C} \mathrm{l}^{-1} \mathrm{~h}^{-1}\right)$ estimated from ${ }^{14} \mathrm{C}$ assimilation by total microplankton $(<200 \mu \mathrm{m})$ over the first 3 to $6 \mathrm{~h}$ of incubation (First day) or the first 3 to $6 \mathrm{~h}$ of the same incubation after an intervening night period (Second day). Overnight denotes the rate of change of particulate carbon $\left(\mu \mathrm{g} \mathrm{C} \mathrm{l}^{-1} \mathrm{~h}^{-1}\right)$ estimated from ${ }^{14} \mathrm{C}$ during the night period. Ranges are $95 \%$ confidence intervals. PQ is the molar ratio of GPP, by $\mathrm{O}_{2}$ method, to particulate carbon fixation, by ${ }^{14} \mathrm{C}$, both measured over $24 \mathrm{~h}$

\begin{tabular}{|ccccc|}
\hline Expt & PQ & First day & Second day & Overnight \\
\cline { 2 - 5 } $12 \mathrm{Apr}$ & 5.3 & $0.498 \pm 0.072$ & $0.364 \pm 0.128$ & $+0.006 \pm 0.042$ \\
$14 \mathrm{Apr}$ & 4.8 & $1.888 \pm 0.290$ & $1.122 \pm 0.670$ & $+0.065 \pm 0.314$ \\
$16 \mathrm{Apr}$ & 4.9 & $1.660 \pm 0.191$ & $2.117 \pm 0.200$ & $+0.164 \pm 0.201$ \\
4 Oct & $\mathrm{na}$ & $2.450 \pm 0.302$ & $1.540 \pm 0.192$ & $+0.0073 \pm 0.081$ \\
5 Oct & 2.4 & $1.420 \pm 0.111$ & $1.720 \pm 0.218$ & $+0.0010 \pm 0.121$ \\
9 Oct & $\mathrm{na}$ & $0.354 \pm 0.057$ & $0.439 \pm 0.113$ & $+0.0449 \pm 0.095$ \\
\hline
\end{tabular}


resuits: the absence of significant overnight loss of tracer from the particulate matter, and the maintenance, on average, of undiminished rates of tracer assimilation after $24 \mathrm{~h}$ of incubation (Table 5). We were limited to the April data set due to scarcity of complete, diurnal, $\mathrm{O}_{2}$ and ${ }^{14} \mathrm{C}$ data at other times.

The equations for tracer flow are given in Fig. 4. We assumed a 12L:12D light cycle, close to the true photoperiod at the time. A PQ (photosynthetic quotient) of 1.25 was assumed in interconverting the modelled carbon fluxes with $\mathrm{O}_{2}$ fluxes. Most of the parameter and pool size values needed for the model (Fig. 4) were available from the carbon budgets (Table 4). However, the relative sizes and cycling rates of the 2 intracellular pools of autotroph carbon were not so defined. Rather, they were treated as unknown variables that could be varied to reproduce the observations. We assumed that the autotrophs were in balanced growth in the sense that the relative sizes of the 2 internal pools would remain constant over $24 \mathrm{~h}$.

Initially, we attempted to reproduce the observations on the assumption that pool $\mathrm{C}_{2}$ (Fig. 4) was zero, i.e. that the autotrophs were a single, homogenous pool of carbon with no internal carbon re-allocation. We could not so reproduce the large PQ's and overnight conservation of particulate tracer $\left(\mathrm{PO}^{14} \mathrm{C}\right)$ even if we drastically altered the sizes and cycling rates of DOC and bacteria pools from the budget estimates. If we assumed that DOC and bacterial pools were smaller and more rapidly cycled, then $\mathrm{PQ}^{\prime} \mathrm{s}$ as large as 4.0

Table 6. Parameter values for the exchange model (Fig. 4) which were judged to yield acceptable reproduction of the Apr results; values not shown were assigned according to the carbon budgets (Table 4). Also shown are the resulting predicted values, versus observed, of photosynthetic quotient ( $\mathrm{PQ} ; 24$ h values), overnight change of $\mathrm{PO}^{14} \mathrm{C}$ (as $\%$ of value at dusk), and second day rate of $\mathrm{PO}^{14} \mathrm{C}$ increase (as \% of rate on first day)

\begin{tabular}{|c|c|c|c|c|}
\hline \multirow{2}{*}{\multicolumn{2}{|c|}{ Parameters }} & \multicolumn{3}{|c|}{ Experiment } \\
\hline & & $12 \mathrm{Apr}$ & $14 \mathrm{Apr}$ & $16 \mathrm{Apr}$ \\
\hline \multicolumn{2}{|c|}{$\mathrm{C}_{2}\left(\mathrm{C}_{2}+\mathrm{C}_{3}\right)$} & 0.20 & 0.05 & 0.05 \\
\hline \multicolumn{2}{|c|}{$\mathrm{a}$} & 0.50 & 0.80 & 0.80 \\
\hline \multicolumn{2}{|l|}{$e_{a}$} & 0.50 & 0.70 & 0.65 \\
\hline \multicolumn{2}{|l|}{$\mathrm{k}_{\mathrm{e}}$} & 0.08 & 0.07 & 0.02 \\
\hline \multicolumn{2}{|l|}{$\mathrm{k}_{\mathrm{s}}$} & 0.02 & 0.0037 & 0.0011 \\
\hline \multicolumn{5}{|c|}{ Predicted vs observed quantities } \\
\hline \multirow[t]{2}{*}{$\mathrm{PQ}$} & Pred. & 5.3 & 4.8 & 4.9 \\
\hline & Obs. & 5.3 & 4.8 & 4.9 \\
\hline \multirow{2}{*}{$\begin{array}{l}\text { Overnight } \\
\mathrm{PO}^{14} \mathrm{C}\end{array}$} & Pred. & +2.0 & +9.0 & +6.0 \\
\hline & Obs. & +1.0 & +3.0 & +10.0 \\
\hline \multirow{2}{*}{$\begin{array}{l}\text { Second day } \\
\mathrm{PO}^{14} \mathrm{C}\end{array}$} & Pred. & 82.0 & 57.0 & 110.0 \\
\hline & Obs. & 73.0 & 60.0 & 127.0 \\
\hline
\end{tabular}

could be predicted but calculated overnight loss of $\left(\mathrm{PO}^{14} \mathrm{C}\right)$ was about $80 \%$. By contrast, with a DOC pool as large and slowly cycled as our budgets indicated, we could predict overnight conservation of $\mathrm{PO}^{14} \mathrm{C}$ but not PQ's substantially larger than 2.0. Whether release of DOC was continuous or restricted to daytime in the model, we could not reproduce our observations with a homogeneous autotroph carbon pool.

We could reproduce our observations, however, by assuming that the autotroph exchanging pool was a small, but rapidly cycled, part of the total autotroph carbon pool and that DOC release occurred only by day (Table 6). Lacking the data necessary to fit the parameters describing the 2-pool autotroph subsystem (e.g. high-resolution ${ }^{14} \mathrm{C}$ time courses) we could only guess at appropriate values for the rate constants connecting the 2 pools. After several such guesses, we arrived at the values shown in Table 6 which, although not precisely reproducing all the observations, came close enough to satisfy us that we had found an acceptable explanation.

The essential features of the successful model included a rapid passage of ${ }^{14} \mathrm{C}$ into the DOC and its retention there (see Fig. 5), which accounted for the large apparent PQ's we measured. Our one measurement of dissolved organic tacer $\left(\mathrm{DO}^{14} \mathrm{C}\right)$ production, on April 14, supported the model by indicating a DOC production rate of $1.85 \mu \mathrm{g} \mathrm{C} \mathrm{l}^{-1} \mathrm{~h}^{-1}$ (vs a POC production rate of $1.00 \mu \mathrm{g} \mathrm{Cl}^{-1} \mathrm{~h}^{-1}$ over $24 \mathrm{~h}$ ). The model predicted a small increase of DOC pool size $(25 \%)$ over $24 \mathrm{~h}$ for Aprii 14 (Fig. 5) but approximate constancy for other dates. The bacteria were predicted to accumulate little ${ }^{14} \mathrm{C}\left(<14 \%\right.$ of $\mathrm{PO}^{14} \mathrm{C}$ at $\left.24 \mathrm{~h}\right)$ and their respiration accordingly to be only a small influence on tracer movement. The interaction of the 2 autotroph pools was of essential importance. The small size and rapid cycling of $\mathrm{C}_{2}$ permitted the rapid movement of ${ }^{14} \mathrm{C}$ into DOC. The relatively slow exchange between $C_{2}$ and $C_{3}$ caused an overnight dilution of the tracer in $\mathrm{C}_{2}$ and thus a renewed net assimilation of tracer upon re-illumination, even when the autotrophs appeared to acheive no net production over $24 \mathrm{~h}$ (April 12). This feature could not be reproduced by assuming that $\mathrm{C}_{2}$ was small and rapidly cycled but did not exchange with $\mathrm{C}_{3}$.

Although not shown in Table 6, the successful simulations also correctly predicted (to within $10 \%$ ) the observed net community production, CP. The model also predicted that short and long-term production estimates from total organic (i.e. POC + DOC) ${ }^{14} \mathrm{C}$ assimilation should be very close to GPP (e.g. Fig. 5). Consistent with this prediction, measured total organic production for April 14 was $2.85 \mu \mathrm{g} \mathrm{C} \mathrm{l}^{-1} \mathrm{~h}^{-1}$, yielding an apparent PQ of 1.53, acceptably close to the value of 1.25 assumed in the budget calculations. 
We do not wish to imply that we have rigorously tested the model (Fig. 4) or excluded other possible models, but rather to show that at least the simplest possible model (a homogeneous autotroph carbon pool) was inadequate to account for the observations. It appears necessary to invoke a functional heterogeneity of autotroph carbon and a diurnal rhythm in DOC release if the results are to be explained primarily in terms of autotroph physiology.

\section{DISCUSSION}

\section{Community and microheterotroph metabolism}

It is necessary to reconcile observations on microheterotroph $(\mathrm{MH})$ activity with the need for a substantial net microplankton production, on average, to subsidize higher trophic levels in the plankton and benthos (Pomeroy 1974, Williams 1981a, Newell \& Linley 1984). Williams (1981a) has shown that if we accept the high bacterial growth efficiency (>50\%) indicated by many measurements of labelled organic substrate assimilation then a substantial bacterial production ( 5 to $25 \%$ of primary production) can be envisaged without needing to postulate a primary production much larger than current estimates for marine microplankton. We conclude, by contrast, that the natural bacteria that we encountered had much lower growth efficiencies (near zero), more characteristic of bacteria growing on detritus or DOC with a high C:N ratio (Newell 1983). If this should be generally true, then measurements of bacterial production in other coastal and shelf waters would extrapolate to a large predicted consumption of primary production similar to our observations.

Our working approximation of zero growth efficiency for the bacteria is undoubtedly an underestimate insofar as it recognizes no bactiverous activity in the $<5$ (April) or $<1 \mu \mathrm{m}$ (October) size fractions (cf. Fuhrman \& McManus 1984, Wright \& Coffin 1984). Further, the validity and interpretation of bacterial growth estimates based on incubations like ours is imperfectly understood at present (Ferguson et al. 1984, Ducklow \& Hill 1985, Li \& Dickie 1985). On the other hand, pre-screening treatments frequently do permit readily measurable increases in bacterial abundance that we certainly did not observe (Ducklow \& Hill 1985). This inclines us to the view that bacterial growth yields were at least at the low end of the previously published range (i.e. 10 to $20 \%$ rather than $80 \%$, and growth rates accordingly low enough to be obscured by statistical errors and a modest grazing pressure. So far as our conclusion on the overall efficiency of $\mathrm{MH}$ production is concerned, moreover, the precise value for bacterial growth efficiency and activity of small bacterivores is not of great importance.

Our $\mathrm{O}_{2}$ production and consumption measurements indicated no positive net community production (CP), except during the diatom bloom, and a large consumption due to $\mathrm{MH}$, whether bacteria or other organisms. Thus, regardless of how we define bacterial growth yield, there is evidently a frequent lack of primary production available for export from the community. This situation is not likely to result from variation of photosynthetic or respiratory quotients within the recognized physiological range (Williams et al. 1979, Burris 1980, Raine 1983). Adverse effects of containment might be involved (e.g. Carpenter \& Lively 1980) but we detected neither a consistent, progressive, impairment of photosynthesis (Table 5) nor a marked proliferation of bacteria (Table 3; cf. Ferguson et al. 1984). It can be expected on the basis of simple trophic models (Smith et al. 1984) and time-course observations of dark bottle $\mathrm{O}_{2}$ consumption (Williams 1984b) that the $\mathrm{O}_{2}$ technique will underestimate both gross primary production (GPP) and community respiration but these effects should not bias the estimate of CP. So far as these recognized potential error sources are concerned, we have no reason to believe that we underestimated CP. Rather, it appears that primary production was commonly dissipated to a large extent by small $\mathrm{MH}$ in our samples. It may well be that our sparse sampling failed to adequately represent more productive episodes (e.g. Platt \& Harrison 1985) or locations (e.g. Fournier et al. 1984) within the Grand Banks system; it is otherwise not obvious how any substantial production at higher trophic levels could be maintained.

\section{Carbon exchange and ${ }^{14} \mathrm{C}$ dynamics}

With the growing emphasis on the view that marine microplankton constitute a community of both autotrophs and heterotrophs has come a renewed examination of what sort of production (sensu Strickland 1960) might be measured by the ${ }^{14} \mathrm{C}$ technique (see Peterson 1980). Theoretical analyses and direct experimental comparisons between ${ }^{14} \mathrm{C}$ and $\mathrm{O}_{2}$ techniques indicate that total organic ${ }^{24} \mathrm{C}$ fixation will yield rates generally within a factor of 2 of GPP even when $\mathrm{MH}$ are active (Jackson 1983, Raine 1983, Williams et al. 1983, Davies \& Williams 1984, Holligan et al. 1984b, Smith et al. 1984). Of the total tracer fixed in organic form, the particulate is normally expected to be much the largest pool (80 to $90 \%$ : Williams 1981a, Jensen 1983, Lancelot 1983, Holligan et al. 1984b). We were therefore surprised to find that, at least in April, particulate ${ }^{14} \mathrm{C}$ fixation often yielded carbon fixation rates about 4 to 
5-fold smaller than either GPP or respiratory demand estimated simultaneously by the $\mathrm{O}_{2}$ technique, and that our budgets (Table 4) required that roughly 50 to $100 \%$ of GPP should be released as DOC.

To some extent, the large extracellular release rates that we infer depend on the acceptance of a simple model (Fig. 4) that attributes all non-autotrophic respiration to bacteria and insists that extracellular release must meet the metabolic demand of the bacteria. For the October samples, these assumptions are especially questionable, and direct extracellular release may be less important than our budgets (Table 4) indicate. We emphasize, however, that there was still good evidence for a large heterotrophic metabolism in the October samples and for a sometimes substantial discrepancy between particulate ${ }^{14} \mathrm{C}$ assimilation and the GPP estimated from $\mathrm{O}_{2}$ changes.

For the April diatom populations we had direct confirmation of the model's predicted, large, rates of dissolved organic ${ }^{14} \mathrm{C}$ production (for April 14, see 'Results'). The methodology that we employed in measuring $\mathrm{DO}^{14} \mathrm{C}$ production has previously yielded very low extracellular release estimates in a marine diatom culture (Smith \& Platt 1984) so there seems no reason to suspect procedural artifacts as such. Further, independent measurements on April 14 and 16 also indicated a rate of $\mathrm{DO}^{14} \mathrm{C}$ production equalling or exceeding the rate of particulate tracer assimilation in 12 and $24 \mathrm{~h}$ incubations at various natural light intensities (R. Geider pers. comm.). It therefore seems necessary to accept the large estimated rates of direct DOC release from the phytoplankton in April, and our tracer flow modelling indicated that the ${ }^{14} \mathrm{C}$ and $\mathrm{O}_{2}$ results could be so reconciled. It is not clear why we observed such large release rates, but nutrient exhaustion may have been a factor insofar as nitrate and silicate were at undetectable levels in our samples while the Chl a concentrations were fairly large (cf. Myklestad 1974).

Previous work with a marine diatom (Thalassiosira pseudonana) in culture (Smith \& Platt 1984, Smith \& Geider 1985) indicated that released DOC derives from an intracellular pool that cycles more rapidly than the bulk cell carbon pool, and thus quickly reaches equilibrium with the added tracer. Other studies of DO ${ }^{14} \mathrm{C}$ production time courses have indicated a similar, rapid, equilibration (Wiebe \& Smith 1977, Lancelot 1979, Larsson \& Hagstrom 1979, Coveney 1982). To account for large and rapid apparent loss of label to DOC in our April experiments, we found it necessary to invoke a small, fast-cycling pool as the source of the DOC and to assume that DOC release was closely coupled to photosynthesis, ceasing entirely at night. Close coupling of release with photosynthesis is consistent with the postulated origin of the DOC in a pool comprising short-term photosynthetic products (Fogg 1983) and with some other recent field observations (Lancelot \& Mathot 1985). It would be most desirable to determine how generally applicable the heterogeneous exchange model might be. Unfortunately, our October data were too incomplete for even the limited testing allowed by our April data.

The extremely low respiration rates that we estimated for the April diatoms (Table 4) presented another similarity with Thalassiosira pseudonana, which appears to have specific respiration rates of $0.1 \mathrm{~d}^{-1}$ or less when in steady-state growth (Smith \& Platt 1984, Smith \& Geider 1985). However, $T$. pseudonana shows substantially higher respiration rates when transferred to darkness or subjected to transient nitrogen deprivation, while the majority of measurements in culture suggest that diatoms may typically respire 10 to $30 \%$ of their photosynthetic assimilation (Harris 1978, Burris 1980). Other field measurements of respiration by diatom-dominated phytoplankton have yielded conflicting results that either agree with our conclusion of very low respiration rates (Smith 1977) or disagree by indicating about $65 \%$ consumption of daily photosynthesis by respiration (Lancelot \& Mathot 1985). The reasons for these discrepant results are not obvious, but they appear to indicate a very substantial variability in the growth efficiency of diatoms in nature.

We note that our simple ${ }^{14} \mathrm{C}$ exchange model not only reproduces the April observations but also predicts that total organic ${ }^{14} \mathrm{C}$ fixation will yield a production estimate close to GPP as estimated by $\mathrm{O}_{2}$ technique. For the one date on which we measured $\mathrm{DO}^{14} \mathrm{C}$ (April 14), this prediction was confirmed: an apparent PQ of 1.5 was obtained over $24 \mathrm{~h}$ of incubation. Thus our April results give some additional support to the growing evidence that total organic ${ }^{14} \mathrm{C}$ fixation provides a production estimate operationally similar to estimated GPP (Williams et al. 1979, 1983, Raine 1983, Holligan et al. 1984b). In April, this agreement was evidently achieved largely because autotroph respiration was small compared to other components of community metabolism, and such appears to have been the case in coastal waters of Hawaii as well (Williams et al. 1983, Laws et al. 1984, Smith et al. 1984). In the latter case, however, it was the retention of ${ }^{14} \mathrm{C}$ label in microheterotroph $(\mathrm{MH})$ biomass, rather than in DOC, that was suggested to account for the agreement of the 2 production measures (Smith et al. 1984). Thus differences in the cycling of ${ }^{14} \mathrm{C}$ during incubation may produce similar results in terms of the correspondence between ${ }^{14} \mathrm{C}$ and $\mathrm{O}_{2}$ based production measures so long as $\mathrm{MH}$ metabolism is dominant.

Acknowledgements. We thank C. Anstey, D. Mossman and J. Anning for help in the field work, E. Horne for CTD measure- 
ments, and W. K.W. Li and S. S. Bates for critical reading of the manuscript. The work was supported in part by the Federal Panel on Energy R \& D (PERD).

\section{LITERATURE CITED}

Azam, F., Fenchel, T., Field, J. G., Gray, J. S., Meyer-Reil, L. A., Thingstad, F. (1983). The ecological role of watercolumn microbes in the sea. Mar. Ecol. Prog. Ser. 10: $257-263$

Bauerfeind, S. (1985). Degradation of phytoplankton detritus by bacteria: estimation of bacterial consumption and respiration in an oxygen chamber. Mar. Ecol. Prog. Ser. 21: $27-36$

Bell, R. T., Kuparinen, J. (1984). Assessing phytoplankton and bacterioplankton production during early spring in Lake Erken, Sweden. Appl. environ. Microbiol. 48: 1221-1230

Bratbak, G., Dundas, I. (1984). Bacterial dry matter content and biomass estimations. Appl. environ. Microbiol. 48: 755-757

Bryan, J. R., Riley, J. P., Williams, P. J. LeB. (1976). A Winkler procedure for making precise measurements of oxygen concentration for productivity and related studies. J. exp. mar. Biol. Ecol. 21: 191-197

Burris, J. E. (1980). Respiration and photorespiration in marine algae. In: Falkowski, P. G. (ed.) Primary productivity in the sea. Plenum, New York, p. 411-431

Carpenter, E. J., Lively, J. S. (1980). Review of estimates of algal growth using ${ }^{14} \mathrm{C}$ tracer techniques. In: Falkowski, P. G. (ed.) Primary productivity in the sea. Plenum, New York, p. 431-462

Coleman, A. W. (1980). Enhanced detection of bacteria in natural environments by fluorochrome staining of DNA. Limnol. Oceanogr. 25: 943-947

Coveney, M. F. (1982). Bacterial uptake of photosynthetic carbon from freshwater phytoplankton. Oikos 38: 8-20

Davies, J. M., Williams, P. J. LeB. (1984). Verification of ${ }^{14} \mathrm{C}$ and $\mathrm{O}_{2}$ derived primary organic production measurements using an enclosed ecosystem. J. Plankton Res. 6: 457-474

Ducklow, H. W. (1983). Production and fate of bacteria in the oceans. Bioscience 33: 491-500

Ducklow, H. W., Hill, S. M. (1985). The growth of heterotrophic bacteria in the surface waters of warm core rings. Limnol. Oceanogr. 30: 239-259

Eppley, R. W., Sharo, J. H., Renger, E. H., Perry, M. J., Harrison, W. G. (1977). Nitrogen assimilation by phytoplankton and other microorganisms in the surface waters of the central north Pacific Ocean. Mar. Biol. 39: 111-120

Fasham, M. J. R. (1985). Flow analysis of materials in the marine euphotic zone. In: Ulanowicz, R. E., Platt, T. (ed.) Ecosystem theory for biological oceanography. Ca. Bull. Fish. Aquat. Sci. 213: 139-162

Ferguson, R. L., Buckley, E. N., Palumbo, A. V. (1984). Response of marine bacterioplankton to differential filtration and confinement. Appl. environ. Microbiol. 47: 49-55

Fogg, G. E. (1983). The ecological significance of extracellular products of phytoplankton photosynthesis. Botanica mar. 26: 3-14

Fournier, R. O., Van Det, M., Hargreaves, N. B., Wilson, J. S., Clair, T. A., Ernst, R. (1984). Physical factors controlling summer distribution of chlorophyll a off southwestern Nova Scotia. Limnol. Oceanogr. 29: 517-526

Fuhrman, J. A., McManus, G. B. (1984). Do bacteria-sized marine eukaryotes consume significant bacterial production? Science $224: 1257-1260$

Harris, G. P. (1978). Photosynthesis, productivity and growth:
The physiological ecology of phytoplankton. Arch. Hydrobiol. Beih. Ergeb. Limnol. 10: 1-171

Herman, A. W., Mitchell, M. R., Young, S. W. (1984). A continuous pump sampler for profiling copepods and chlorophyll in the upper oceanic layers. Deep Sea Res. 31: 439-450

Holligan, P. H., Harris, R. P., Newell, R. C., Harbour, D. S., Head, R. N., Linley, E. A. S., Lucas, M. I., Tranter, P. R. G., Weekly, C. M. (1984a). Vertical distribution and partitioning of organic carbon in mixed, frontal, and stratified waters of the English Channel. Mar. Ecol. Prog. Ser. 14; 111-127

Holligan, P. M., Williams, P. J. LeB., Purdie, D., Harris, R. P. $(1984 \mathrm{~b})$. Photosynthesis respiration and nitrogen supply of plankton populations in stratified frontal and tidallymixed shelf waters. Mar. Ecol. Prog. Ser. 17: 201-213

Jackson, G. A. (1983). Zooplankton grazing effects on ${ }^{14} \mathrm{C}-$ based phytoplankton production measurements: a theoretical study. J. Plankton Res. 5: 83-94

Jensen, L. M. (1983). Phytoplankton release of extracellular organic carbon, molecular weight composition, and bacterial assimilation. Mar. Ecol. Prog. Ser. 11: 39-48

Joint, I. R., Morris, R. J. (1982). The role of bacteria in the turnover of organic matter in the sea. Oceanogr. mar. Biol. A. Rev. 20:65

Laanbroek, H. J., Verplanke, J. C., de Visscher, P. R. M., de Vuyst, R. (1985). Distribution of phyto- and bacterioplankton growth and biomass parameters, dissolved inorganic nutrients and free amino acids during a spring bloom in the Oosterschelde Basin. The Netherlands. Mar. Ecol. Prog. Ser. 25: 1-11

Lancelot, C. (1979). Gross excretion rates of natural marine phytoplankton and heterotrophic uptake for excreted products in the southern North Sea, as determined by shortterm kinetics. Mar. Ecol. Prog. Ser. 1: 179-186

Lancelot, C. (1983). Factors affecting phytoplankton extracellular release in the Southern Bight of the North Sea. Mar. Ecol. Prog. Ser. 12: 115-121

Lancelot, C., Mathot, S. (1985). Biochemical fractionation of primary production by phytoplankton in Belgian coastal waters during short and long term incubations with ${ }^{14} \mathrm{C}$ bicarbonate. I. Mixed diatom population. Mar. Ecol. Prog. Ser. 86: 219-226

Larsson, M., Hagstrom, A. (1979). Phytoplankton exudate release as an energy source for the growth of pelagic bacteria. Mar. Biol. 52: 199-206

Laws, E. A., Redalje, D. G., Haas, L. W., Bienfang, P. K. Eppley, R. W., Harrison, W. G., Karl, D. M., Marra, J. (1984). High phytoplankton growth and production rates in oligotrophic Hawaiian coastal waters. Limnol. Oceanogr. 29: 1161-1169

Li, W. K. W. Dickie, P. M. (1985). Growth of bacteria in seawater filtered through $0.2 \mu \mathrm{m}$ Nuclepore membranes: implications for dilution experiments. Mar. Ecol. Prog. Ser. 26: 245-252

Myklestad, S. (1974). Production of carbohydrates by marine planktonic diatoms. I. Comparison of nine different species in culture. J. exp. mar. Biol. Ecol. 15: 261-274

Newell, R. C. (1983). The biological role of detritus in the marine environment. NATO Advanced Research Institute. In: Fasham, M. J. (ed.) Flow of energy and materials in marine ecosystems. Plenum Press, New York, p. 317-343

Newell, R. C., Linley, E. A. S. (1984). Significance of microheterotrophs in the decomposition of phytoplankton: estimates of carbon and nitrogen flow based on the biomass of plankton communities. Mar. Ecol. Prog. Ser. 16: 105-119 
Packard, T. T., Williams, P. J. LeB. (1981). Rates of respiratory oxygen consumption and electron transport in surface seawater from the northwest Atlantic. Oceanologica Acta 4: $351-358$

Peterson, B. J. (1980). Aquatic primary productivity and the ${ }^{14} \mathrm{CO}_{2}$ method: a history of the productivity problem. Ann. Rev. Ecol. Syst. 11: 369-385

Peterson, B. J. (1984). Synthesis of carbon stocks and flows in the open ocean mixed layer. In: Hobbie, J. E., Williams, P. J. LeB. (ed.) Heterotrophic activity in the sea. Plenum, New York, p. 547-554

Platt, T., Harrison, W. G. (1985). Biogenic fluxes of carbon and oxygen in the ocean. Nature, Lond. 318: 55-58

Pomeroy, L. R. (1974). The ocean's food web, a changing paradigm. Bioscience 24: 499-504

Porter, K. G., Feig, Y S. (1980). The use of DAPI for identifying and counting aquatic microflora. Limnol. Oceanogr. 25: 943-947

Raine, R. C. T (1983). The effect of nitrogen supply on the photosynthetic quotient of natural phytoplankton assemblages. Botanica mar. 26: 417-423

Servais, P., Billen, G., Rego, J. V (1985). Rate of bacterial mortality in aquatic environments. Appl. environ. Microbiol. 49: 1448-1454

Smith, R. E. H., Platt, T. (1984). Carbon exchange and ${ }^{14} \mathrm{C}$ tracer methods in a nitrogen limited diatom, Thalassiosira pseudonana. Mar. Ecol. Prog. Ser. 16: 75-87

Smith, R. E. H., Geider, R. J. (1985). Kinetics of intracellular carbon allocation in a marine diatom. J. exp. mar Biol. Ecol. 93: 191-210

Smith, R. E. H., Geider, R. J., Platt, T. (1984). Microplankton productivity in the oligotrophic ocean. Nature, Lond. 311 : $252-254$

Smith, W. O. (1977). The respiration of photosynthetic carbon in eutrophic areas of the ocean. J. mar. Res. 35: 557-565

Strickland, J. D. H. (1960). Measuring the production of marine phytoplankton. Bull. Fish. Res. Bd Can. 122

Van Es, F. B., Meyer-Reil, L. A. (1982). Biomass and metabolic activity of heterotrophic marine bacteria. In: Marshall, $\mathrm{K}$ C. (ed.) Advances in microbial ecology. Plenum, New York, p. 111-170

Wiebe, W J., Smith, D. F. (1977). Direct measurement of dissolved organic carbon released by phytoplankton and incorporated by microheterotrophs. Mar. Biol. 42: 213-223

Williams, P. J. LeB. (1981a). Incorporation of microheterotrophic processes into the classical paradigm of microheterotrophic processes into the classical paradigm of the planktonic food web. Kieler Meeresforsch. (Sonderh.) 5 $1-28$

Williams, P. J. LeB. (1981b). Microbial contribution to overall marine plankton metabolism: direct measurements of respiration. Oceanologica Acta 4: 359-364

Williams, P. J. LeB. (1984a). Bacterial production in the marine food chain: the Emperor's new suit of clothes? In: Fasham, M. J. (ed.) Flows of energy and materials in marine ecosystems. Plenum, New York, p. 271-299

Williams, P. J. LeB. (1984b). A review of measurements of respiration rates of marine plankton populations. In: Hobbie, J., Williams, P. J. LeB. (ed.) Heterotrophic activity in the sea. Plenum, New York, p. 357-390

Williams, P. J. LeB., Jenkinson, N. W (1982). A transportable microprocessor controlled precise Winkler titration suitable for field station and shipboard use. Limnol. Oceanogr. 27: 576-584

Williams, P. J. LeB., Raine, R. C. T., Bryan, J. R. (1979). Agreement between the ${ }^{14} \mathrm{C}$ and oxygen methods of measuring phytoplankton production: re-assessment of the photosynthetic quotient. Oceanologica Acta 2: $411-416$

Williams, P. J. LeB., Heinemann, K. R., Marra, J., Purdie, D. A. (1983). Comparison of ${ }^{14} \mathrm{C}$ and $\mathrm{O}_{2}$ measurements of phytoplankton production in oligotrophic waters. Nature, Lond. 305: 49-50

Wright, R. T., Coffin, R. B. (1984). Measuring microheterotrophic grazing of marine bacterioplankton with differential filtration and incubation. Microb. Ecol. 10: 137-150 